\title{
Factors Influencing Entrepreneur Choice of Franchising as a Business Model: The Case of Mankweng Township in the Limpopo Province of South Africa
}

\author{
Olabanji. A. Oni \\ Khutso. E. Sekwele \\ Tafadzwa Matiza \\ Gert Pelser \\ Department of Business Management, University of Limpopo, Turfloop Campus, \\ Private Bag X1106, Sovenga, 0727, South Africa \\ Email: matizata@hotmail.com
}

\section{Doi:10.5901/mjss.2014.v5n9p111}

\section{Abstract}

This study explored the factors that influenced the choice of entrepreneurs located in the Mankweng Township of Limpopo Province, South Africa, of franchising as a business model in establishing a fast food business. The study also sought to determine the managerial requirements the respondents believed were necessary to establish a franchise that is located in a peri-urban area, primarily catering to a rural population. The study was qualitative in nature and utilised the survey approach to data collection. Seven interviews were conducted within the purposively sampled population, with the semi-structured interview schedule as the choice of data generation instrument. As a result of this study it emerged that the influencers to entrepreneur choice to adopt franchising in this area were explicitly linked to the established benefits of franchising, while the inherent managerial skills of entrepreneurs were largely key to the success of franchise businesses in Mankweng Township. The study ultimately concludes that both influencers and managerial skill requirements are universal to both urban and peri-urban franchising and recommends that amongst other recommendations, entrepreneurs critically evaluate the market, with particular reference to particular franchises and the potential benefits they offer.

Keywords: Entrepreneur, franchising, franchise choice, managerial skills, Mankweng

\section{Introduction}

Franchising as a business model has made significant inroads in small to medium size business development in South Africa. Franchising is essentially a pre-packaged business with established policies and procedures (Branford \& Bruton, 2011). According to Brendt, (2009), there are 551 franchised systems in South Africa, managing over 30000 outlets which employ over 500000 people. The franchise business sector contributes up to $12.5 \%$ of South Africa's gross domestic product (GDP- Erasmus, Strydom, \& Kloppers, 2013, Brent, 2009). The most common forms of franchise systems are product and trade name franchises, business format franchises and joint venture franchises (Co, Groenwald, Mitchell, Nayager \& Visser, 2007). In South Africa franchising is dominant in the fast food industry, given its convenience to customers and dependence brand loyalty and standardization.

The overall aim of the survey is to determine the factors influencing the selection of franchising as a business option and the competencies and systems required in managing a franchise to maintain a good standard in the franchise business. This study is with particular reference to the Mankweng township of Limpopo Province, South Africa, which is located 30 kilometres from the provincial capital of Limpopo Province, Polokwane, and services a number of rural villages and peri-urban settlements. To achieve this, the study sought to a) Establish the factors influencing entrepreneurs to select franchising as a business option; and b) Determine the managerial skills required to operate the business. With this in mind the study addressed the following significant questions:

- What are the factors influencing the choice of franchising as a business option for business people located in the Mankweng township of Limpopo province, South Africa?

- What are the managerial skills required to operate a franchise from the perspective of franchisee's located in the Mankweng township of Limpopo province, South Africa? 


\section{Review of Related Literature}

Franchising as a marketing system revolves around a two-party legal agreement whereby the franchisee is granted the privilege to sell a product or service and conduct a business as an individual owner, but is required to operate according to the methods and terms of the franchisor (Longenecker, Moore \& Petty, 2003). According to the seminal work of Hamid, Othman, Selamat and Mastor (2003) franchising as a business model is smart, systematic, efficient and effective and involves a form of business cloning where franchisers seek to have franchisees replicate their business in their local community. This is achieved by establishing an entire business concept, including product or service, trade mark and methods of operations (Hoffman \& Prebles, 1993 cited in Hamid, Othman, Selamat \& Mastor, 2003). While the Franchise Association of South Africa ( FASA- 2004 cited in Co et al, 2007)) views franchising as an arrangement between the franchisor (the business owner) and the franchisee (the entrepreneur) entitling the franchisee to utilise the complete business systems that the franchisor has developed.

\subsection{Factors influencing the choice of franchising}

The inherent benefits of franchising as a business model are the key influencers of the decision of entrepreneurs opting for franchising instead of establishing a new business. According to Honey (n.d) the success of franchising is based on the fact that in the case of established franchise brands consumers have an existing familiarity with the product, service and quality. This familiarity greatly reduces the risk of business failure. Literature (Beshel, 2001, Holmes, 2003, Boone \& Kurtz, 2010) identifies the following amongst the benefits of franchising as a business model, which for the purposes of this study invariably constitute the factors that influence the choice of franchising by entrepreneurs as a business model in the fast food industry;

- Prior performance record - unlike establishing an unknown business, a franchise offers an existing and tested business model which informs the potential franchisee of business performance in that particular product offering.

- Recognisable company name/brand - franchising offers business owners the advantage of brand recognition and goodwill as soon as the business is set up. This implies that the franchisee has a competitive advantage based on the existing brand loyalty of the franchise.

- Successful business model - with particular reference to new business failure, franchising offers an established and tested business model which reduces the risk of new venture failure.

- Business training and management program - franchises offer training programs and operator manuals to assist in the establishment and running of the new business respectively. This support is not readily available when establishing a new business.

However, some of the above mentioned benefits of franchising as influencers of the uptake of franchising as a business model, may be regarded as factors that dissuade some new business owners from investing in a franchise as a new business venture. These include;

- Franchisee fees - apart from the initial investment, franchisees are expected to pay royalty fee to the franchise owners based on profits generated by the business.

- Risk of unprofitability - as with any other new business, franchising also carries the risk of not being profitable due to a myriad of factors. This is compounded by the requirements of franchisee fees.

- Franchise agreement restrictions - franchise businesses are strictly managed according to the franchise agreement, which often limits the business owners' ability to innovate.

- No brand and reputation control - brand management including marketing and promotions are determined by the franchisor. Franchisees therefore have no control over the reputation of the brand as well as branding direction. (Boone, 2010).

The above mentioned factors affect the choices of entrepreneurs in the selection of business model. Linked to these influencers are the managerial skills that entrepreneurs need to possess in order to both identify profitable franchises and manage them effectively.

\subsection{Managerial skills of entrepreneurs in franchising}

The managerial skills required for effective franchise management are similar to those required for the establishment and effective management of a new venture. According to Dubrin (2008), to be effective, managers need to possess certain 
skills and to this end The Business Harvard Review (2013) points out that managerial skills represent knowledge to fulfil some activities or task. This knowledge can be learned and be required through practical implementation of franchise activities. Whatever the level of management, a manager needs a combination of some or all of the following skills; a) risk aversion skills, b) system orientation skills, c) coach-ability skills, d) hard-work affinity, e)planning skills, f) inter-personal skills and; g) conceptual skills (Elgin, 2003, Dubrin, 2008, Nieman \& Nieuwenhuizen, 2009). These management skills apply in equal measure to the management of franchises in addition to the operating procedures and support provided by franchise owners.

\section{Methodology}

The main function of the research design is to enable researcher to anticipate appropriate decisions, to maximize the validity of results through either minimizing or where possible eliminating potential errors. This study was conducted as a qualitative study which can be described as aiming to gather an in-depth understanding of human behaviour and the reasons that govern such behaviours. The study was exploratory in nature and adopted the survey approach, conducting face to face interviews as they are well suited to explorative studies (Gerber-Nel, Nel \& Kotze, 2005, Uma \& Roger, 2009, Ihua, 2009). According to Polit, Beck and Hungler (2001), explorative studies are undertaken when a new area is being investigated or when little is known about an area of interest. Little is known about the factors influencing franchise decisions and the managerial skills required of franchise businesses in the Mankweng area of Limpopo Province, South Africa.

\subsection{Population and Sample}

Defining the universal population is the first and critical step in the sampling process. According to Uma \& Roger (2009) the population of the research is defined as the entire group of people, events or things of interest that the researcher wishes to investigate. The universal population for this study is all the fast food franchise businesses in the Mankweng area. The Mankweng area is comprised of eight fast food brand outlets of which two franchises are managed by one owner. Purposive sampling of all franchise business owners was implemented for the study due to the small number of fast food franchises available in the Mankweng area. Hence for this study, the final sample frame is all franchise business owners in the Mankweng area, resulting in a population of $N=7$ since two franchises in the area have one owner.

\subsection{Data Collection and Analysis}

Data for this study was collected using the survey technique; data for the research study was gathered through interviews. The researcher used an interview schedule as the data collection instrument as it ensured anonymity and privacy of the respondents, thereby encouraging more candid and honest responses and; ensured a higher response rate than other data gathering techniques such as mail surveys (Cooper \& Schindler, 2003).

The researcher used a semi-structured interview schedule as a survey instrument to determine the factors influencing performance in franchising in the Mankweng area. The interview schedule was comprised of open and closeended questions to establish the critical factors considered by the respondents in selecting franchising as a business approach and the skills they consider to be key to franchise success. The interview schedule was based on five sections and the main topics covered are in the Table 1 below:

Table 1: Topics covered in the interview schedule

\begin{tabular}{|l|l|}
\hline section $\mathbf{A}:$ & $\begin{array}{l}\text { section } \mathbf{B} \\
\text { Managerial skills requires to operate a franchise }\end{array}$ \\
\hline The demographic information & $\begin{array}{l}\text { section } \mathbf{D} \\
\text { section } \mathbf{C}\end{array}$ \\
The factors influencing entrepreneurs select franchise as a business option & The development of a measure of franchise business \\
\hline section $\mathbf{E}$ \\
The general questions about franchise business
\end{tabular}

\section{Results}

The following are the results of study conducted; 


\subsection{Demographics}

Respondents (Table 2) were within the age group of 25-44. Of the respondents, $57 \%$ (4) are $25-34$ years; while $43 \%$ (3) are 35-44 years. There were no respondents of the age of 45 and older. The results indicate that majority of franchise owners in the Mankweng area are in their early adult age. Of the seven respondents, five (71\%) were male and two $(29 \%)$ were female. The results also indicated that the majority have post matric qualifications. This implies that the respondents were well educated and were able to give informed responses to the questions. It is also interesting to note that more than $50 \%$ of the respondents had degrees.

Table 2: Demographic information of franchise owners

\begin{tabular}{|c|c|c|c|c|c|}
\hline \multicolumn{2}{|c|}{ Gender } & \multicolumn{2}{c|}{ Age } & \multicolumn{2}{c|}{ Educational education } \\
\hline Male & Female & $25-34$ & $35-44$ & Post-matric Diploma & Post-Graduate Degree \\
\hline $71 \%$ & $29 \%$ & $57 \%$ & $43 \%$ & $71 \%$ & $29 \%$ \\
\hline
\end{tabular}

Source: Field Data

\subsection{The factors influencing entrepreneurs in Mankweng Township to select franchising as a business option}

The respondents were asked to mention the factors influencing them to select franchise as business option by answering yes or no to specific factors based on the literature review. Table 3 summarizes the responses:

Table 3: Factors influencing entrepreneurs to select franchising as a business option

\begin{tabular}{|l|c|}
\hline \multicolumn{2}{|c|}{ Factors influencing entrepreneurs to select franchising as a business option } \\
\hline Training provided by franchise holder & $100 \%$ \\
\hline Financial assistance & $43 \%$ \\
\hline The cost of starting the business & $86 \%$ \\
\hline Lower Risk & $100 \%$ \\
\hline Operating benefits & $100 \%$ \\
\hline Managerial advice and support & $100 \%$ \\
\hline Independence or ownership & $86 \%$ \\
\hline
\end{tabular}

Source: Field Data

From their responses, the following reasons were given;

\subsubsection{Training}

Of the respondents, $100 \%$ were influenced to select franchising as a business option because of the training provided. The respondents pointed out that it is the franchisor's responsibility to provide suitable training so that the franchisee can be able to run a franchise outlet competently. In most cases training is an important advantage of the franchising system. The most important of the training programme as they pointed out was the operational manual which acts as a franchisee textbook during training and serves quality control mechanism. The manuals are explicit, written as if the franchisee has absolutely no experience in the industry and no prior skills. This therefore acted as an extension of the franchise agreement. Most franchise owners received training in cash register operation, hiring and training point of sale system and management of the business as well as daily problems. Participants were adequately trained in the day-to-day running of the business, franchisors lived up to the promise they made and therefore respondents indicated they were willing to renew the contractual agreement if expire.

\subsubsection{Financial assistance}

Financing a franchise is incredibly expensive even though the franchisee may have the skills, the experience and determination necessary to make a business successful. Of the franchisees in Mankweng, $43 \%$ of respondents chose to 
operate a franchise due to the financial assistance from franchisor for the start-up cost. The financial assistance was given based on the credit history of the franchisee. The respondents also pointed out that the cost of buying franchise business is very expensive; however they not at liberty to disclose the value of the business due to the confidentiality of the information.

\subsubsection{Risk available in managing a franchise}

Operating a franchise is less risky because there is a higher chance of being successful than just starting a business from scratch. Apart from that, $100 \%$ of franchise owners at Mankweng intimated they were risk averse and preferred to take the lower risk.

\subsubsection{The operating benefits}

Operating a franchise business is an opportunity to run a proven business concept with a successful operational track record. $100 \%$ of respondents stated that selecting franchise as a business option was a great choice as most franchises are widely known and accepted. The franchise business is a nationally advertised trademark and it is recognised nationally. The parent companies that own the franchise originally developed the product and service and thereafter appointed the franchise owner (respondent) to use its name and the sell the products.

The respondents agreed that they resorted to buying a franchise business rather than starting a business from scratch due to the fact that franchising is a way of doing business that is built on systems and procedures that systematises business operations. A franchise is also built on a premise where all units operate under a common brand and operating systems. This is how consumers know that a franchise is the same, whether they buy at Mankweng, Polokwane or Johannesburg. The franchise business ensures that every franchisee is doing business in the same way and the business is supporting and reinforcing the brand.

\subsubsection{The managerial advice and support}

$100 \%$ of respondents were not aware of the practical running of the business until a franchisor provided not only technical training but also mentoring and career growth opportunities for franchisees. $57 \%$ of franchise owners only had completed a business related course at a tertiary institution and have practically applied their little knowledge in the work situation and it would have been very hard for them to effectively run the business without the supervision and support of the franchisor. $43 \%$ of respondents mentioned that franchisors do not offer the same degree of training and support during the launch or start-up of the franchise business, some franchisors only provide start-up operations and everything after the start-up is up to the franchisee while some promised on-going support but never live up to the promises they have made.

\subsubsection{Independence}

Buying a franchise business is an opportunity of becoming your own boss. Therefore, $86 \%$ of respondents choose franchising as a business option because they want to become their own boss. They want to control their own destiny and build the business by themselves. However, the overall advantage of buying a franchise for the respondents was its probability to succeed.

\subsection{The managerial skills required to operate the business}

For managers to be effective, they have to possess certain skills and knowledge. This knowledge or skills can be learned and acquired through practical implementation of activities. Whatever the level of management, a manager needs a combination of some or all the skills depicted in Table 4, 
Table 4: Managerial skills required to operate a franchise business option

\begin{tabular}{|l|c|}
\hline \multicolumn{2}{|c|}{ Managerial skills required to operate a franchise business } \\
\hline Risk aversion skills & $100 \%$ \\
\hline Coach-ability skills & $100 \%$ \\
\hline Planning skills & $100 \%$ \\
\hline Interpersonal skills & $100 \%$ \\
\hline Conceptual skills & $100 \%$ \\
\hline Knowledge of competitors & $100 \%$ \\
\hline Survive strict competition & $86 \%$ \\
\hline Have knowledge and skills with regard to the business & $100 \%$ \\
\hline Focus on applying themselves to developing and effectively portraying skills through their actions & $100 \%$ \\
\hline Have enough ambition to run the business & $100 \%$ \\
\hline
\end{tabular}

Source: Field Data

The above table summarizes the questions that were asked to respondents in the form of closed-ended questions. The respondents were asked to indicate the managerial skills that they believe they require in order to operate a franchise business by placing a tick next to the relevant option provided; i.e. yes or no and then were asked to comment on them. The purpose of this section is to help franchise owners to recognise their need for key managerial skills both for themselves and the staff members. Many businesses fail because the owner does not have the required managerial skills to operate the business.

From the results of the interview, $100 \%$ of respondents indicated that they believed they had the managerial skills required to operate a franchise. The interview provided ten generic managerial skills necessary in order to operate a franchise business effectively. From their responses, the following reasons were given:

\subsubsection{Risk aversion}

Buying a franchise may be less risky than starting a business from scratch, but it requires courage and commitment. Of the respondents, $100 \%$ mentioned they were risk averse. Respondents, preferred to make investments that were of lower risk and controllable. Buying a franchise itself is a big risk, however, franchising is a better option for risk-averse entrepreneurs who would rather not opt for becoming stand-alone small business owners. This is because the franchisees accept the risk of introducing the franchisor's concept to a new and untried market and therefore the franchisor's risk will be spread over the entire business whereas the franchisee's capital is tied up in the franchise.

\subsubsection{Coach-ability skills}

Of the seven franchise owners, $100 \%$ of the respondents believe that they had coach-ability skills; this is due to their response they gave that it is unlikely that they will ever manage a team where everyone is adequately trained. The franchise owners were able to identify team or staff member training needs and able to get them trained in order to achieve the best level of performance. The respondents who are coachable are also motivated. Effective coaching requires having enough motivation to try new things and dedicated to the process.

\subsubsection{Planning skills}

Planning was established to be key for every franchise owners needs to develop and hone. From their responses, 100\% of respondents have planning skills. Franchise owners believe that planning improves their chances of success and it is a tool that enables them to achieve a given aim.

\subsubsection{Interpersonal skills}

The respondents believed that interpersonal skills were a natural and life skill that they use every day to communicate and interact with individuals and groups. Of the respondents, $100 \%$ of respondents believed that they had acquired interpersonal skills and therefore, this skill helps to develop both professionally and through personal relationships. As 
successful franchise owners, the respondents tended to work closely with people and this is critical because franchise owners must build a great relationship with teams, customers and suppliers. Some people are more gifted in this skill than others, but every entrepreneur can learn and improve this skill it emerged.

\subsubsection{Conceptual skills}

Conceptual skills entail recognising how the various units of the organisation depend on one another and how changes in any one part affect all the others. This is an important skill that the interviewed franchise owners and from their responses, $100 \%$ of respondents believe that they have conceptual skills; this skill therefore helped respondents to be able to conceive new ideas and also re-think of new procedures and processes.

\subsubsection{Knowledge of competitors}

Every business has competitors. When buying a franchise business, it is important to assess competitive landscape in order to have strong sense as to who is targeting the same customers. $100 \%$ of franchise owners in the Mankweng area have knowledge about their competitor's strengths and weaknesses in order for their businesses to survive and succeed in the market. To survive, it is important for franchise owners to outperform competitors in order to gain competitive advantage.

\subsubsection{Survive strict competition}

To survive strict competition, it is important for franchise owners to know whom they are competing with because these days where every product is selling, there are other thousands others providing the same product. Of the respondents, $100 \%$ of franchise owners believe that they can and still will survive strict competition in the Mankweng area. However, the strategy here is to create an identity and image that set the franchise business apart from those of competitors because buyers make choices and buy products according to brand identity. In most cases, they rely on the perception, impression or quality of the product that the business is selling.

\subsubsection{Knowledge and skills with regard to the business}

Business knowledge before operating or starting a business is critical. Many people have tried to start or buy an existing business without bothering to acquire the business knowledge they need to make their business a success. 100\% of franchise owners in the Mankweng area are knowledgeable about many different aspects of business and have many different skills with regard to managing the day-to-day operation of the franchise business. The respondents provided that sales, marketing and managing people are set of skills needed in a business that requires being successful.

\subsubsection{Have enough ambition to run the business}

Starting a business is an ambition for many people, but very few actually make it happen. Of the participants, 100\% of respondents believed that they had enough ambition to run the day-to-day running of the franchise business. Being ambitious enables franchise owners to set goals and once accomplished they aim even higher goal.

Managerial skills and business knowledge are an indication of how well a franchise owner can perform important tasks and activities related to the functions of a business. In order to run a successful business, franchise owners still expressed the need for a diverse range of business skills apart from the ones mention above. These skills may include sales and marketing, accounts, human resources and information technology. However, it also emerged that it was important for franchise owners to acquire as many skills applicable to the daily operation of the business because there are certain factors that can jeopardise their development and which may of course lead to business close down.

\section{Discussion and Recommendations}

This study explored the factors influencing the choice of franchising as a business approach for fast food business entrepreneurs in the Mankweng Township area of Limpopo Province, South Africa. The study also explored the managerial skills that the respondents believed were vital for the effective and efficient management of their franchise 
businesses. The study concludes that the generic influencers of franchising choice by entrepreneurs equally applied to entrepreneurs who established franchises in the peri-urban area of the Limpopo Province of South Africa. It also emerged that the generic managerial skills inherent in entrepreneurs also applied in equal measure to entrepreneurs undertaking to successfully establish and manage franchises. This study therefore, concludes that based on the findings of the survey the established benefits of franchising were the catalyst for the intention of the interviewees to establish fast food franchises in the Mankweng Township. Similarly, generic management skills and attributes were more or less universal regardless of the location of the franchise, with all the respondents having had a post-high school qualification.

Based on the findings of this study it is recommend that new entrepreneurs considering establishing fast food franchises in peri-urban centres such as Mankweng Township in Limpopo Province which cater to a largely rural population should:

a) Each individual entrepreneur must self-evaluate based on their business interests, managerial skills and potential, with particular reference to the franchise they wish to invest in.

b) Due to the nature of the rural population entrepreneurs must be cognoscente of the particular franchise product they wish to sell, evaluate potential competitors and the positioning the franchise would have in that market segment.

c) The entrepreneur should also consider the competitive strength of the franchise in relation to related franchises, and

d) Individual entrepreneurs looking to buy into a franchise that offers the relevant management and operational support, franchise history and corporate expansion strategy.

\section{References}

Beshel Barbara. (2001). An introduction to franchising. New York: The IFA Educational Foundation.

Boone, L.E \& Kurtz D.L (2010). Contemporary Business, $13^{\text {th }}$ Ed. MA: John Wiley \& Sons Inc.

Branford, C.E \& Bruton, G.D. (2011). Entrepreneurship: A small business approach. New York: McGraw Hill.

Brendt, A. (2001). Franchise satisfaction among food franchisees: an exploratory study. Southern African Business Review, 13(1), pp120.

Co, Mary. J, Groenewald, June, Mitchell, B, Nayager, T \& Visser, K. (2007). Entreprenuership: Fresh Perspectives. Capetown: Pearson Prentice Hall.

Cooper, D.R. \& Schindler, P.S. (2003). Business Research Methods. New York: McGraw Hill Inc.

Dubrin, J.A. (2008). Essentials of management, 8th Ed. Canada: South-Western Cengage Learning.

Elgin, F. (2003). Top 5 Characteristics of Successful Franchisees. [Online] Available:http://www.entrepreneur.com/article 160986\#ixzz2V3cLQopc. (Accessed 30 May 2013.)

Erasmus, B.J, Strydom, J.W \& Rudorsky-Kloppers, S. (2013). Introduction to business management, $9^{\text {th }}$ Ed. Capetown: Oxford University Press.

Franchise Association of South Africa. (2014). [Online] Available: www.fasa.co.za (Accessed February 14, 2014).

Gerber-Nel, C., Nel, D. \& Kotze, T. (2005). Marketing research. Claremont: New Africa Books (Pty) Ltd.

Hamid, A.B.A, Othman, M.H.M, Selamat, R. \&Mastor, N. (2003). An Encouraging Factor for Entrepreneur in Franchising. A Malaysia Experience. Vol 16, pp 24

Holmes, D.E. (2003). The advantages and disadvantages of franchising. [Online] Available: www.holmeslofstrom.com (Accessed February14, 2014).

Ihua, U.B. (2009). SMEs Key Failure-Factors: A comparison between the United Kingdom and Nigeria. Journal for Social Science, 18(13), pp199-207.

Lashley, C \& Morrison, A (eds). (2000) Franchising hospitality services. Oxford: Butterworth Heinemann.).

Longenecker, J.G., Moore, C.W., Palich, L.E. \& Petty, J.W. (2006).Small business management: An entrepreneurial Emphasis, $13^{\text {th }}$ Ed. Thomson South-Western United States of America.

Nieman, G, Hough, J \& Niewenhuizen, C. (2003). Entrepreneurship: A South African perspective. Pretoria: Van Schaik.

Nieman, G. \&Nieuwenhuizen, C. (2009).Entrepreneur: A South African Perspective. Pretoria: Van Schaik Publisher.

Pilot, D., Beck, C., \&Hungler, B. (2001). Essential of Nursing Research methods, Appraisal and Utilization, $5^{\text {th }}$ Ed. Philadelphia: J.B Lippincott Co.

Sen, K.C (1998). The use of franchising as a growth strategy by U.S restaurant franchisors. Journal of Consumer Marketing, 15(4). Pp$397-407$.

Uma, S. \& Roger, B. (2009) .Research methods for business: A skill building Approach. 5th Ed. United Kingdom: John Wiley and Sons Ltd.

Van Aardt, I, van Aardt, C \& Bezuidenhout, S. (2003). Entrepreneurship and new venture management: An Introduction. Pretoria: Van Schaik. 